\title{
Penerapan Pembelajaran Problem Based Learning Untuk Meningkatkan Hasil Belajar Siswa Pada Materi Pokok Keliling dan Luas Bangun Datar di SDN 01 Terong Tawah
}

\author{
M. Zainal Mustamiin \\ Program Studi Bimbingan dan Konseling, FIPP UNDIKMA \\ Email:mzainalmustamiin@yahoo.com
}

\begin{abstract}
Abstrak: Kesulitan siswa dalam memahami konsep-konsep dalam mata pelajaran matematika merupakan salah satu faktor yang mempengaruhi hasil belajar siswa pada mata pelajaran matematika. Oleh karena itu diperlukan suatu tindakan yang memperbaiki proses pembelajaran dan meningkatkan hasil belajar. Salah satu pembelajaran inovatif yaitu model pembelajaran problem based learning. Tujuan yang ingin di capai di dalam penelitian ini adalah untuk mengetahui peningkatan hasil belajar siswa Jenis penelitian yang digunakan dalam penelitian ini adalah menggunakan pendekatan penelitian tindakan kelas yang dianalisis dengan rumus persentase pada hasil belajar dan aktivitas diukur dengan dengan rumus skor aktivitas belajar. Berdasarkan hasil penelitian diketahui bahwa rata-rata aktivitas siswa untuk pertemuan I sebesar 68,23\% yang tergolong cukup aktif dan pertemuan II adalah 70,63 \% tergolong kategori cukup aktif. Sedangkan pada siklus II rata-rata aktivitas siswa untuk pertemuan I adalah 74,86 \% yang tergolong aktif dan pada pertemuan II adalah 79,20 $\%$ juga tergolong aktif. Untuk nilai rata-rata kelas siklus I sebesar 71,45 dengan persentase ketuntasan belajar $64 \%$ dan pada siklus II nilai rata-rata ketuntasan belajarnya adalah 81,29 dengan persentase ketuntasan belajar sebesar $88 \%$. Kesimpulan dari penelitian ini adalah model pembelajaran problem based learning dapat meningkatkan hasil belajar siswa pada materi pokok keliling dan luas bangun datar di kelas IV SDN 01 Terong Tawah Tahun Pelajaran 2019/ 2020. Dengan model pembelajaran problem based learning aktivitas siswa dalam pembelajaran mengalami peningkatan.
\end{abstract}

Kata kunci: hasil belajar, problem based learning

\section{Latar Belakang}

Pendidikan merupakan upaya untuk mencapai dan mengarahkan seseorang menuju kedewasaan. Tujuan pendidikan menurut UU No.22 Tahun 2003 adalah “ Pendidikan nasional bertujuan mencerdaskan kehidupan bangsa dan mengembangkan manusia seutuhnya, yaitu manusia yang bertaqwa terhadap Tuhan Yang Maha Esa dan berbudi luhur, memiliki pengetahuan dan keterampilan, kesehatan jasmani dan rohani, keperibadian yang mantap dan mandiri serta bertanggung jawab kemasyarakatan dan kebangsaan "(Sagala, 2008:3).

Pendidikan mempunyai peranan penting bagi setiap bangsa untuk membangun negaranya. Pembangunan hanya bisa dilakukan oleh manusia yang dipersiapkan melalui pendidikan. Proses pendidikan berarti didalamnya menyangkut kegiatan belajar mengajar dengan segala aspek dan faktor yang mempengaruhi. Pada hakekatnya untuk menunjang tercapainya tujuan pembelajaran, maka dalam proses tersebut menuntut terjadinya proses belajar mengajar yang optimal. Dengan optimalisasi proses belajar mengajar tersebut diharapkan para peserta didik dapat meraih hasil belajar yang memuaskan.

Keberhasilan pembelajaran dapat diamati dari dua sisi yaitu pemahaman dan penguasaan materi yang diberikan. Makin tinggi tingkat penguasaan dan pemahaman 
materi, makin tinggi pula keberhasilan pembelajaran tersebut. Setiap pembelajaran memang tidak terlepas dari kesulitan materi yang dipelajarinya. Dengan mengetahui kesulitan belajar guru dapat mengambil manfaat untuk perbaikan.

Berdasarkan hasil wawancara di kelas IV SDN 01 Terong Tawah bahwa nilai pelajaran matematika rata-rata dibawah nilai KKM yang telah ditentukan oleh sekolah yaitu 65, itu disebabkan karena model pembelajaran yang digunakan dalam proses belajar mengajar matematika masih kurang. Dalam pembelajaran matematika diperlukan kesabaran dan ketelitian karena siswa kurang memahami konsep-konsep dasar matematika, kurang memahami pengertian-pengertian materi dan kurang menguasai materi tersebut.

Oleh karena itu diperlukan suatu tindakan untuk memperbaiki proses pembelajaran dan diharapkan terjadinya peningkatan hasil belajar. Salah satu model pembelajaran yang sesuai dengan kurikulum 2006 yang dikembangkan sekarang adalah Pembelajaran Berbasis Masalah (Problem-Based-Learning). Pengajaran ini menggunakan masalah dunia nyata sebagai suatu konteks belajar bagi siswa tentang cara berfikir kritis dan ketrampilan pemecahan masalah. Dengan pembelajaran berbasis masalah diharapkan siswa dapat mengembangkan keterampilan berfikir dalam memecahkan masalah dan menjadi pembelajar yang mandiri sehingga hasil belajar siswa meningkat. Disamping itu juga dapat membantu siswa belajar keterampilan pemecahan masalah dengan melibatkan mereka pada situasi nyata (Ibrahim dan Nur, 2000).

\section{TINJAUAN PUSTAKA}

\section{Hasil Belajar}

Hasil belajar merupakan kemampuan dasar yang digunakan untuk menentukan tingkat keberhasilan siswa dalam memahami dan menguasai materi pembelajaran.

Sebagaimana telah diungkap oleh Engkoswara (1984:2) hasil belajar berarti suatu proses perubahan tingkah laku, baik dalam bentuk prestasi yang telah direncanakan. Prestasi dapat berupa penugasan, penggunaan atau penilaian terhadap sikap dan nilai pengetahuan keterampilan.

Syaiful Sagala (2003:23) mengatakan bahwa hasil belajar merupakan suatu ungkapan pernyataan hasil interaksi dan proses perolehan pengetahuan oleh peserta didik.

Dari uraian di atas dapat disimpulkan hasil belajar dapat dilihat dari perubahan-perubahan dalam pengetahuan, sikap dan keterampilan yang bersifat konsisten.

Hasil belajar merupakan perubahan perilaku yang diperoleh pembelajar setelah mengalami aktivitas belajar. Hasil belajar adalah pola-pola perbuatan, nilai-nilai, pengertian-pengertian, sikap-sikap, apresiasi dan keterampilan.

Merujuk pemikiran Gagne, hasil belajar berupa:

1) Informasi verbal yaitu kapabilitas mengungkapkan pengetahuan dalam bentuk bahasa, baik lisan maupun tertulis.

2) Keterampilan intelektual yaitu kemampuan mempersentasikan konsep dan lambang. Keterampilan intelektual merupakan kemampuan melakukan aktivitas kognitif bersifat khas. 
3) Strategi kognitif yaitu kecakapan menyalurkan dan mengarahkan aktivitas kognitifnya sendiri. Kemampuan ini meliputi penggunaan konsep dan kaidah dalam memecahkan masalah.

4) Keterampilan motorik yaitu kemampuan melakukan serangkaian gerak jasmani dalam urusan dan koordinasi, sehingga terwujud otomatisme gerak jasmani.

5) Sikap adalah kemampuan menerima atau menolak objek berdasarkan penilaian terhadap objek tersebut. Sikap merupakan kemampuan menjadikan nilai-nilai sebagai standar perilaku. (Agus Suprijono, 2009:5-6).

\section{Model Pembelajaran Problem Based Learning}

Model pembelajaran problem based learning adalah model pembelajaran dengan pendekatan pembelajaran siswa pada masalah autentik sehingga siswa dapat menyusun pengetahuannya sendiri, menumbuhkembangkan ketrampilan yang lebih tinggi dan inkuiri, memandirikan siswa, dan meningkatkan kepercayaan diri sendiri (Arends, 2000:12).

Model ini bercirikan penggunaan masalah kehidupan nyata sebagai sesuatu yang harus dipelajari siswa untuk melatih dan meningkatkan ketrampilan berfikir kritis dan memecahkan masalah, serta mendapatkan pengetahuan konsep-konsep penting, di mana tugas guru harus memfokuskan diri untuk membantu siswa mencapai keterampilan mengarahkan diri. Pembelajaran berbasis masalah penggunaannya di dalam tingkat berfikir yang lebih tinggi, dalam situasi berorientasi pada masalah, termasuk bagaimana belajar.

Dalam model pembelajaran problem based learning, guru berperan sebagai penyaji masalah, penanya, mengadakan dialog, membantu menemukan masalah dan pemberi fasilitas penelitian. Selain itu guru menyiapkan dukungan dan dorongan yang dapat meningkatkan pertumbuhan inkuiri dan intelektual siswa. Pembelajaran berbasis masalah hanya dapat terjadi jika guru dapat menciptakan lingkungan kelas yang terbuka dan membimbing pertukaran gagasan. Pembelajaran berbasis masalah juga dapat meningkatkan pertumbuhan dan perkembangan aktivitas siswa, baik secara individual maupun secara kelompok. Pada model pembelajaran berbasis masalah guru berperan pemberi rangsangan, pembimbing kegiatan siswa dan penentu arah belajar siswa.

\section{Tinjauan Materi}

Keliling dan Luas Bangun Datar

1. Keliling dan Luas Segitiga

Segitiga adalah bangun datar dengan 3 buah sisi dan 3 buah sudut.

Jenis-jenis segitiga yaitu:

1. Segitiga sama sisi yaitu segitiga yang ketiga sisinya sama panjang.

2. Segitiga sama kaki yaitu segitiga yang mempunyai dua sisi sama panjang.

3. Segitiga siku-siku yaitu segitiga yang salah satu sudutnya siku-siku.

4. Segitiga sembarang yaitu segitiga yang sisi-sisinya atau sudut-sudutnya sembarang.

5. Segitiga lancip yaitu segitiga yang masing-masing sudutnya lancip.

6. Segitiga tumpul yaitu segitiga yang salah satu sudutnya tumpul.

\section{A. Keliling Segitiga}

Keliling adalah ukuran panjang sisi yang mengitari bangun datar.

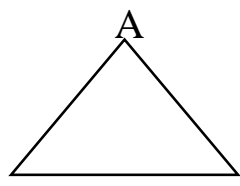


B C

Keliling segitiga ABC adalah jumlah panjang sisi-sisinya. Sehingga dapat ditulis sebagai berikut :

$$
\mathrm{K}=\mathrm{AB}+\mathrm{AC}+\mathrm{BC}
$$

Contoh

Tentukan keliling segitiga $\mathrm{ABC}$ berikut ini

a.

$\mathrm{B}$

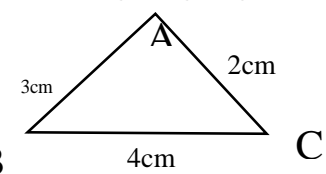

Jawab :

$$
\text { a. } \begin{aligned}
K & =A B+A C+B C \\
& =3 \mathrm{~cm}+4 \mathrm{~cm}+2 \mathrm{~cm} \\
& =9 \mathrm{~cm} .
\end{aligned}
$$

\section{B. Luas segitiga}

Luas segi tiga $\mathrm{ABC}$ adalah :

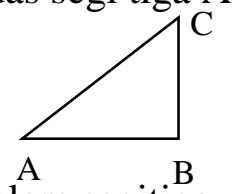

$$
L=\frac{1}{2} \times \text { Panjang } x \text { Lebar }
$$

Dalam segitiga, tidak ada ukuran panjang dan lebar. Sisi bawah disbut alas (a) dan sisi tegak disebut tinggi $(\mathrm{t})$. sehingga luas segi tiga dirumuskan :

$$
\mathrm{L}=1 / 2 \times \text { alas } \mathrm{x} \text { tinggi }
$$

\section{Contoh :}

Tentukan luas segi tiga $\mathrm{ABC}$ berikut ini

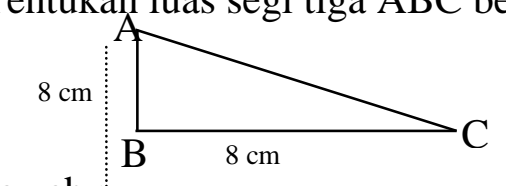

Jawab :

$$
\begin{aligned}
\mathrm{L} & =\frac{\text { alasxtinggi }}{2} \\
\mathrm{~L} & =\frac{8 \mathrm{~cm} \times 8 \mathrm{~cm}}{2} \\
\mathrm{~L} & =32 \mathrm{~cm}^{2}
\end{aligned}
$$

\section{METODE PENELITIAN}

Metode pengumpulan data yang digunakan dalam penelitian ini adalah;

a. Metode dokumentasi 
Metode ini dilakukan dengan mengambil dokumen atau data-data yang mendukung penelitian meliputi data tentang siswa dan hasil belajar yang diperoleh yang akan diambil saat penelitian.

b. Metode tes

Metode tes ini digunakan untuk mengukur hasil belajar siswa. Sebelum soal digunakan, terlebih dahulu di uji cobakan pada kelas di luar kelas penelitian.

C. Metode observasi

Observasi yang dilakukan dalam penelitian kelas ini meliputi observasi psikomotorik dan afektif siswa, observasi kinerja guru dan observasi aktivitas siswa. Observasi kinerja guru (peneliti) dilakukan oleh guru kelas, sedangkan untuk observasi terhadap siswa dilaksanakan secara kolaborasi oleh peneliti dan guru kelas.

\section{HASIL PENELITIAN}

1. Analisa Data Penelitian Siklus I

a) Tahap Perencanaan

Pada tahap perencanaan ini peneliti dan guru menyiapkan skenario pembelajaran, lembar observasi dan pembentukan kelompok yang terdiri dari 5 kelompok. Sebelum peneliti mengelompokkan siswa yang berkemampuan akademis tinggi, sedang dan kurang, maka peneliti melihat hasil nilai raport semester genap siswa kemudian tiaptiap kelompok terdiri dari 5 orang siswa. Dimana 1 siswa berkemampuan akademis tinggi, 2 siswa berkemampuan akademis sedang dan 2 siswa berkemampuan akademis kurang, selanjutnya peneliti menyusun tes evaluasi hasil belajar.

b) Tahap pelaksanaan tindakan

Pada tahap tindakan ini dimana pada tahap tindakan ini berisi penyampaian materi keliling dan luas segitiga yang sebelumnya guru memberikan masalah yang berkaitan dengan materi yang akan disampaikan, dilanjutkan dengan diskusi kelompok dan pemberian latihan melalui LKS secara individual. Semuanya dilaksanakan melalui pembelajaran berbasis masalah sebagai berikut.

1) Sebelum pembelajaran berbasis masalah dilaksanakan guru terlebih dahulu menyampaikan tujuan pembelajaran dan mengimformasikan model pembelajaran yang akan digunakan serta memberikan motivasi kepada siswa dengan menceritakan kehidupan sehari-hari yang berkaitan dengan materi yang akan disampaikan.

2) Tahap-tahap pembelajaran berbasis masalah sebagai berikut.

a) Mengorientasi siswa pada masalah

Guru mengajukan masalah yang terkait dengan pokok keliling dan luas bangun datar.

b) Mengorganisasikan siswa untuk belajar

Pada tahap ini guru membagi siswa kedalam kelompok yang terdiri dari lima kelompok dan meminta setiap kelompok untuk menggunakan ide dari kelompoknya sendiri menyelesaikan masalah yang diberikan.

c) Membimbing penyelidikan individual maupun kelompok

Guru mengaktifkan diskusi dalam kelompok dan berkeliling memantau kerja masing-masing kelompok serta membantu kelompok yang mengalami kesulitan.

d) Mengembangkan dan menyajikan hasil karya

Masing-masing kelompok diberi kesempatan untuk mempersentasikan hasil kerja kelompoknya dan menanggapi hasil pemecahan kelompok lain. Guru mengamati siswa dan membimbing siswa yang mengalami kesulitan. 
e) Menganalisis dan mengevaluasi proses pemecahan masalah Guru membantu siswa dalam mengkaji ulang proses atau hasil pemecahan masalah dan memberi penguatan terhadap hasil pemecahan masalah siswa. Kemudian untuk mengetahui pe pemahaman siswa guru membagikan LKS untuk dikerjakan secara individu.

3) Penutup

Guru membimbing siswa untuk merangkum atau menarik kesimpulan.

c) Tahap observasi/ evaluasi

1) Data Hasil Belajar Siswa

Data ringkasan hasil belajar siswa siklus I dapat dilihat pada tabel berikut ini.

Tabel 1

Ringkasan Data Hasil Evaluasi Belajar Siswa Siklus I

\begin{tabular}{|c|c|c|c|c|c|}
\hline $\begin{array}{c}\text { Jumlah } \\
\text { siswa }\end{array}$ & $\begin{array}{c}\text { Total } \\
\text { nilai }\end{array}$ & $\begin{array}{c}\text { Nilai } \\
\text { rata-rata }\end{array}$ & $\begin{array}{c}\text { Banyak } \\
\text { siswa yang } \\
\text { tuntas }\end{array}$ & $\begin{array}{c}\text { Banyak } \\
\text { siswa yang } \\
\text { tidak tuntas }\end{array}$ & $\begin{array}{c}\text { Persentase } \\
\text { ketuntasan }\end{array}$ \\
\hline 25 & 1757 & 70,28 & 16 & 9 & $64 \%$ \\
\hline
\end{tabular}

(Sumber : Lampiran 13)

d) Refleksi

Dari hasil data yang diperoleh pada siklus I menunjukkan bahwa belum tercapainya hasil yang diharapkan. Oleh karena itu penelitian dilanjutkan pada siklus II.

Berdasarkan refleksi terhadap tindakan pada siklus I perlu dilanjutkan dengan memberikan tindakan pada siklus II. Ini dilakukan untuk penyempurnaan dan perbaikan kendala-kendala yang ada pada siklus I. adapun kendala-kendala yang ada pada siklus I adalah :

1. Kurangnya motivasi siswa dalam menerima materi yang diberikan sehingga mengakibatkan siswa kurang memperhatikan guru pada saat menjelaskan materi pelajaran.

2. Kurangnya kerjasama dalam kelompok sehingga komunikasi antar individu maupun kelompok sangat kurang. Siswa yang kemampuan akademisnya tinggi kurang mau bekerjasama dengan siswa yang kemampuan akademisnya rendah dan sebaliknya siswa

3. yang akademisnya rendah enggan bertanya pada teman kelompoknya.dan kurangnya keberanian untuk menjawab pertanayaan dari guru sehingga menjadi penyebab belajar tidak efektif

Untuk mengatasi kendala-kendala yang dihadapi pada siklus I, solusi yang dilakukan pada siklus II adalah sebagai berikut :

1. Memotivasi siswa untuk lebih memperhatikan guru pada saat menjelaskan materi pelajaran.

2. Memberikan pengarahan akan pentingnya kerjasama antar anggota kelompok.

3. Memotivasi siswa agar lebih berani untuk bertanya, mengajukan pendapat dan berani menjawab pertanyaan yang diberikan oleh guru.

\section{Analisis Data Pada Siklus II}

a. Tahap Perencanaan 
Tahap perencanaan pada siklus II pada prinsipnya sama seperti pada siklus I dengan menerapkan pembelajaran Problem Based Learning dengan memperhatikan kekurangan-kekurangan pada siklus I.

\section{b. Tahap Pelaksanaan}

Tahap pelaksanaan ini dilaksanakan, dimana pada tahap pelaksanaan ini berisi penyampaian materi keliling dan luas jajar genjang, dilanjutkan dengan pemberian LKS. Semuanya dilaksanakan melalui tahapan pembelajaran berbasis masalah sebagai berikut.

1) Sebelum pembelajaran berbasis masalah dilaksanakan guru terlebih dahulu menyampaikan tujuan pembelajaran dan mengimformasikan model pembelajaran yang akan digunakan serta memberikan motivasi kepada siswa dengan menceritakan kehidupan sehari-hari yang berkaitan dengan materi yang akan disampaikan. Kemudian guru memberikan apersepsi dengan tanya jawab.

2) Tahap-tahap pembelajaran berbasis masalah sebagai berikut.

a) Mengorientasi siswa pada masalah

Guru mengajukan masalah yang terkait dengan keliling dan luas jajar genjang.

b) Mengorganisasikan siswa untuk belajar

Pada tahap ini guru membagi siswa ke dalam 5 kelompok yang terdiri dari 5 siswa setiap kelompoknya dan meminta setiap kelompok untuk menggunakan ide dari kelompoknya sendiri menyelesaikan masalah yang diberikan pada tahap pertama dan memberikan sebuah masalah kepada setiap kelompok.

c) Membimbing penyelidikan individual maupun kelompok

Guru mengaktifkan diskusi dalam kelompok dan berkeliling memantau kerja masing-masing kelompok serta membantu kelompok yang mengalami kesulitan.

d) Mengembangkan dan menyajikan hasil karya

Masing-masing kelompok diberi kesempatan untuk mempersentasikan hasil kerja kelompoknya dan menanggapi hasil pemecahan kelompok lain. Guru mengamati siswa dan membimbing siswa yang mengalami kesulitan.

e) Menganalisis dan mengevaluasi proses pemecahan masalah

Guru membantu siswa dalam mengkaji ulang proses atau hasil pemecahan masalah dan memberi penguatan terhadap hasil pemecahan masalah siswa.

Tabel 4

Ringkasan Hasil Observasi Aktivitas Siswa Siklus II

\begin{tabular}{|c|c|c|c|c|c|}
\hline No & Pertemuan & $\begin{array}{c}\text { Jumlah } \\
\text { Nilai }\end{array}$ & $\begin{array}{c}\text { Rata- } \\
\text { rata }\end{array}$ & Persentase & Kategori \\
\hline 1 & I & 655 & 26,2 & 74,86 & Aktif \\
\hline 2 & II & 693 & 27,72 & 79,20 & Aktif \\
\hline
\end{tabular}

(Sumber: Data Lampiran 11 dan 12)

Berdasarkan kriteria penggolongan kategori aktif aktivitas belajar siswa dalam proses belajar mengajar yang sudah ditetapkan bahwa kategori aktivitas belajar siswa pada siklus II tergolong aktif dengan masing-masing rata-rata persentase aktivitas belajar siswa adalah 74,86\% untuk pertemuan I dan 79,20\% untuk pertemuan II.

c. Refleksi 
Berdasarkan hasil yang diperoleh pada siklus II dengan nilai rata-rata kelas 78,04 dan persentase ketuntasan belajar siswa adalah $88 \%$ serta persentase rata-rata aktivitas belajar siswa pertemuan I dan II adalah $75 \%$ yang tergolong aktif. Jadi dari hasil penelitian yang dilakukan dari siklus I sampai siklus II ini dapat disimpulkan bahwa terdapat peningkatan hasil belajar siswa dan aktivitas belajar siswa dengan menggunakan pembelajaran problem based learning pada pembelajaran matematika pada pokok keliling dan luas bangun datar.

Dari hasil yang diperoleh pada siklus II ternyata target yang diterapkan kurikulum telah tercapai, sehingga dengan demikian pada siklus berikutnya dapat dihentikan, tetapi ada beberapa siswa yang masih di bawah yang ditargetkan oleh kurikulum, maka sangat perlu mendapatkan perhatian khusus dari guru yang bersangkutan. Perhatian yang dimaksud di sini adalah memberikan bimbingan belajar khusus maupun bimbingan sosial yang sesuai dengan siswa yang bersangkutan.

\section{PEMBAHASAN}

Berdasarkan hasil penelitian pada tiap-tiap siklus, menunjukkan bahwa hasil dari siklus ke siklus mengalami peningkatan. Pada siklus I menunjukkan bahwa nilai rata-rata kelas sebesar 70,28 dengan persentase ketuntasan sebesar 64\%, ini menunjukkan bahwa ketuntasan belajar siswa belum mencapai target yang ditetapkan oleh kurikulum. Hal ini disebabkan oleh kerjasama dalam kelompok masih sangat kurang dalam proses pembelajaran dengan menggunakan pembelajaran problem based learning, ditambah lagi dengan kurangnya keberanian siswa untuk bertanya, kurangnya keberanian siswa untuk mengacungkan tangan untuk bertanya, mengemukakan pendapat dan kurangnya keberanian siswa menjawab pertanyaan yang dilemparkan oleh guru. Untuk mengatasi hal tersebut guru melakukan perbaikan-perbaikan dalam proses belajar mengajar serta meningkatkan hal-hal yang masih dianggap kurang. Berdasarkan analisa data pada siklus I bahwa rata-rata persentase aktivitas siswa untuk pertemuan I sebesar 68,23\% yang tergolong aktif dan pertemuan II adalah 70,63\% tergolong kategori aktif. Dari persentase belajar siswa, aktivitas belajar siswa dalam proses pembelajaran belum mencapai target yang ditetapkan oleh kurikulum. Oleh karena itu perlu adanya perbaikan pada siklus II.

Pada siklus II guru melakukan penyempurnaan dan perbaikan-perbaikan kekurangan pada siklus I dengan memberikan perbaikan-perbaikan diantaranya adalah sebagai berikut: guru menentukan atau memilih tutor sebaya untuk tiap-tiap kelompok untuk membantu atau mengajari temannya yang belum paham tentang materi yang dipelajari dan guru menekankan kepada siswa bahwa suatu kelompok dikatakan berhasil apabila tiap-tiap anggota kelompok paham tentang materi yang dipelajari dan bias menjawab pertanyaan yang dilemparkan oleh guru dengan benar. Guru memotivasi siswa untuk lebih berani dan tidak malu-malu untuk bertanya kepada temannya, guru mengingatkan pentingnya tugas kelompok agar semua anggota kelompok memiliki tanggung jawab yang sama atas masalah yang ada pada kelompoknya. Guru menekankan pada siswa bahwa tiap kelompok yang maju persentase harus semua anggota kelompoknya berani dan bisa mengemukakan pendapat dari hasil kerja mereka. Pada siklus II ini guru memfokuskan pada pemberian perhatian untuk semua kelompok dan lebih meningkatkan pada cara membimbing siswa dalam proses pembelajaran.

Berdasarkan hasil analisa data pada siklus II menunjukkan bahwa rata-rata nilai kelas sebesar 78,04 dengan ketuntasan belajar siswa adalah 88\%, hal ini menunjukkan 
bahwa tercapainya ketuntasan belajar yang ditargetkan oleh kurikulum yaitu dengan ratarata nilai kelas minimal 65 dengan persentase ketuntasan belajar siswa minimal 85\%. Dan persentase rata-rata aktifitas siswa pada siklus II untuk pertemuan I adalah sebesar $74,86 \%$ yang tergolong aktif dan 79,20\% untuk pertemuan II juga tergolong aktif.

Berdasarkan hasil analisa data pada siklus I menunjukkan rata-rata nilai kelas sebesar 70,28 dengan ketuntasan belajar siswa sebesar 64\% yang tergolong cukup aktif. Ini menunjukkan bahwa belum tercapainya ketuntasan belajar yang ditargetkan oleh kurikulum yaitu dengan nilai rata-rata kelas 65 dengan ketuntasan belajar siswa minimal $85 \%$. Sedangkan persentase nilai rata-rata aktifitas siswa pada siklus I pertemuan I adalah sebesar $68,23 \%$ yang tergolong aktif.

Berdasarkan hasil analisa data rata-rata kelas, ketuntasan belajar siswa dan aktifitas belajar siswa pada siklus I adalah masing-masing sebesar 70,28 dan 68,23\% yang tergolong aktif untuk pertemuan I dan aktivitas belajar untuk pertemuan II adalah 70,63\% dengan kategori aktif. Sedangkan pada siklus II nilai rata-rata kelas, ketuntasan belajar siswa dan aktivitas belajar siswa diperoleh sebesar $88 \%$ dan aktivitas belajar untuk pertemuan I sebesar 74,86\% serta 79,20\% untuk pertemuan II dengan kategori keduanya tergolong aktif. Apabila kita melihat dari siklus ke siklus, maka diperoleh peningkatan pada siklus I dan pada siklus II dengan nilai rata-rata kelas ketuntasan belajar siswa dan aktivitas belajar siswa dengan peningkatan masing-masing adalah 70,28 (nilai rata-rata evaluasi siklus I); 78,04 (nilai rata-rata evaluasi siklus II); 68,23\% (rata-rata persentase aktivitas belajar siklus I) ke 79,20\% (rata-rata persentase belajar siklus II).

Dengan penerapan pembelajaran problem based learning dalam pembelajaran matematika dapat membawa siswa pada berperan aktif dan mengikut sertakan kemajuan yang dimiliki oleh siswa, maka dengan demikian pemahaman tentang suatu materi dapat diterima oleh siswa dengan baik. Karena dengan mencampurkan para siswa dengan kemampuan yang beragam, maka siswa yang kurang akan sangat membantu dan termotivasi siswa yang lebih, demikian juga siswa yang lebih akan semakin terasah pemahamannya. Ini berarti bahwa penerapan pembelajaran problem based learning dalam pembelajaran matematika dapat meningkatkan hasil belajar siswa dan aktivitas belajar siswa, dengan demikian pembelajaran problem based learning diterapkan pada materi pokok keliling dan luas bangun datar.

\section{KESIMPULAN}

Dapat kita tarik kesimpulan bahwa :

1) Dengan penerapan pembelajaran problem based learning pada materi pokok keliling dan luas bangun datar dapat meningkatkan hasil belajar siswa kelas IV SDN 01 Terong Tawah Tahun Pelajaran 2019/2020. Hal ini dibuktikan dengan hasil analisis, dimana pada siklus I mempunyai nilai ketuntasan 64\% dengan nilai rata-rata 70,28 sedangkan pada siklus II mengalami peningkatan dengan nilai ketuntasan $88 \%$ dengan nilai rata-rata 78,04.

2) Bahwa aktivitas siswa dari siklus ke siklus mengalami peningkatan dengan nilai ratarata persentase aktivitas siswa pada siklus I pertemuan I adalah $68,23 \%$ dan pertemuan II sebesar $70,63 \%$ sedangkan pada siklus II pertemuan I adalah $74,86 \%$ dan untuk pertemuan II sebesar 79,20\%.

\section{DAFTAR PUSTAKA}


Abbas, Nurhayati. (2000). Pengembangan Perangkat Pembelajaran Matematika Berorientasi Model Pembelajaran Berbasis Masalah (Problem Based Instruction). Program Studi Pendidikan Matematika Pasca Sarjana. UNESA.

Arikunto, Suharsimi. (1997). Prosedur Penelitian. Jakarta: Rineka Cipta.

Darsono, Max, dkk. (2000). Belajar dan pembelajaran. Semarang: IKIP Semarang.

Ibrahim, Muslimin dan Nur. (2000). Pembelajaran Berdasarkan Masalah. Surabaya: UNESA.

Mulyasa, E. (2003). Kurikulum Berbasis Kompetensi. Bandung : Remaja Rosdakarya.

Nuryenti, Diah Eko. (2005). Model Pembelajaran Berbasis Masalah Untuk mengembangkan kecakapan Matematika Siswa Sekolah Dasar (SD) Kelas III Sebagai Implementasi Kurikulum Berbasis Kompetensi (KBK). Skripsi S1 Pendidikan UNNES.

Riduwan. (2005). Belajar Mudah Penelitian Untuk Guru, Karyawan, dan Peneliti Pemula. Bandumg: Alfabeta.

Suyitno, Amin. 2004. Dasar-dasar Proses Pembelajaran Matematika. Semarang: Jurusan Matematika.

Sudjana, Nana, (2005). Dasar-dasar Proses Belajar Mengajar. Bandung: Sinar Baru.

Sugiyono. (2003). Statistik Untuk Penelitian. Bandung: Alfabeta.

Sagala, Syaipul, (2008). Konsep dan Makna Pembelajaran (Untuk Membantu Memecahkan Problematika Belajar dan Mengajar). Bandung: Alfabeta.

Suwarsih Madia. (2007). Teori dan Praktik Penelitian Tindakan (Action Research). Bandung: Alfabeta.

Poerwadarminta, W. J. S. (1984). Kamus Umum Bahasa Indonesia. Jakarta: Balai Pustaka. 